\title{
Potassium in shrink-swell soils of India
}

\author{
Priya P. Gurav ${ }^{1, *}$, S. K. Ray ${ }^{2}$, P. L. Choudhari ${ }^{3}$, A. O. Shirale ${ }^{1}$, B. P. Meena ${ }^{1}$, \\ A. K. Biswas ${ }^{1}$ and A. K. Patra ${ }^{1}$ \\ ${ }^{1}$ Division of Soil Chemistry and Fertility, ICAR-Indian Institute of Soil Science, Nabibagh, Bhopal 462 038, India \\ ${ }^{2}$ Regional Centre, ICAR-National Bureau of Soil Survey and Land Use Planning, Jorhat 785 004, India \\ ${ }^{3}$ CRAL-International Crops Research Institute for the Semi-Arid Tropics, Development Centre, Asia Program, Patancheru, Hyderabad 502 324, India
}

\begin{abstract}
This article reviews the information regarding potassium (K) status of Indian soils based on research conducted since 1929. The patterns and lacunae regarding potassium consumption in India are also mentioned. The role of minerals in potassium availability vis-à-vis forms of potassium is discussed and elucidated with suitable clay mineralogical evidences. The article also highlights the problems of potassium availability to plants in Indian shrink-swell soils. We have pointed out the inefficacy of the universal method used for assessing plant-available $K$ (1N $\mathrm{NH}_{4} \mathrm{OAc}$ ) in Indian shrink-swell soils, as observed from extensive $K$ response studies. The current practices of assessing only plant-available $K$ is not adequate to detect native changes in soil potassium. This paradoxical situation necessitates revision and revalidation of the existing potassium fertilizer recommendations, which are being adopted since four decades. A holistic research envisaging soil test crop response and mineralogical studies will help in revising potassium evaluation methods in India, leading to judicious fertilizer application by the farmers.
\end{abstract}

Keywords: Clay mineralogy, fertilizers, mineralogy, potassium availability, swell-shrink soils.

THE shrink-swell (cracking clay) soils are primarily found in Peninsular India, expanding from $8^{\circ} 45^{\prime} \mathrm{N}$ to $26^{\circ} 0^{\prime} \mathrm{N}$ lat. and $68^{\circ} 0^{\prime} \mathrm{E}$ to $83^{\circ} 45^{\prime} \mathrm{E}$ long. Predominantly, these shrink-swell soils are developed from the weathering of Deccan lava ${ }^{1}$ occupying an area of about $116 \mathrm{~m}$ ha in the country ${ }^{2}$. These soils are smectite-rich with sufficient reserves to supply potassium $(\mathrm{K})$ to the plants ${ }^{3}$.

Potassium is often considered as the quality element for crop production ${ }^{4}$, and is recognized as a quality-plusyield nutrient. It helps promote photosynthates translocation as well as mobilization of stored material ${ }^{5}$. The major role of $\mathrm{K}$ is stomatal opening and closing which maintain the transpiration of water, and penetration of atmospheric $\mathrm{CO}_{2}$ into the leaf which helps in improving water use efficiency ${ }^{6}$.

The net negative balance for NPK in the current agricultural scenario is $19 \%$ for $\mathrm{N}, 12 \%$ for $\mathrm{P}$ and $69 \%$ for $\mathrm{K}$. The enormous proportion of potassium is because crops

*For correspondence. (e-mail: priyaguravnbss@gmail.com) remove an average 1.5 times more potassium than nitrogen and application of $\mathrm{K}$ through fertilizer is considerably lower than that of $\mathrm{N}$ or $\mathrm{P}$ (refs 3,7 ). The $\mathrm{K}$ balance is negative in almost all the intensive cropping systems in India, since the addition of $\mathrm{K}$ rarely matches its removal, resulting in huge $\mathrm{K}$ mining. This situation creates great pressure on non-exchangeable $\mathrm{K}$ for meeting the potassium requirements of the plants. The long-term intensive cropping systems, without $\mathrm{K}$ inputs, unfavourably affect $\mathrm{K}$ supply for plant uptake, ultimately hindering yield of the crops ${ }^{8,9}$. Hence, it is inevitable to consistently focus on the role and importance of potassium in sustainable crop production by following balanced nutrient management. In order to maintain soil fertility, the removal of $\mathrm{K}$ needs to be balanced by sufficient $\mathrm{K}$ inputs. Hitherto, in India, there was a general consideration that black soils are rich in $\mathrm{K}$ and therefore $\mathrm{K}$ application was dispensable. However, with time it is predicted that in some soils deficiency of potassium could occur due to leaching loss, continuous cropping and soil erosion. In a nutshell, this article reviews the work done on potassium in Indian shrink-swell soils, helping to decipher the potassium behaviour from mineralogical signatures.

\section{Potassium in soil}

Potassium is an essential element for all types of plants and animals for completing their life cycle. It is the seventh most abundant element in the earth crust. The soils contain $0.04-3 \%$ potassium, the total $\mathrm{K}$ content of the upper $0.2 \mathrm{~m}$ of most agricultural soils generally ranges from 10 to $20 \mathrm{~g} \mathrm{~kg}^{-1}$ (refs 9-11). However, most of the soil potassium (90-98\%) is chemically bound in the crystal lattice structure of minerals, and thus not directly available or slowly available for plant uptake. The availability of $\mathrm{K}$ varies considerably from soil to soil, and is affected by different soil properties. Potassium in soil is categorized into four groups based on its availability to plants, viz. water-soluble, exchangeable, non-exchangeable/fixed and structural/mineral $\mathrm{K}$.

Water-soluble potassium is the form of $\mathrm{K}$ which is directly available for plants and microorganisms; the $\mathrm{K}$ content mostly depends on depletion as well as replenishment of exchangeable and non-exchangeable 


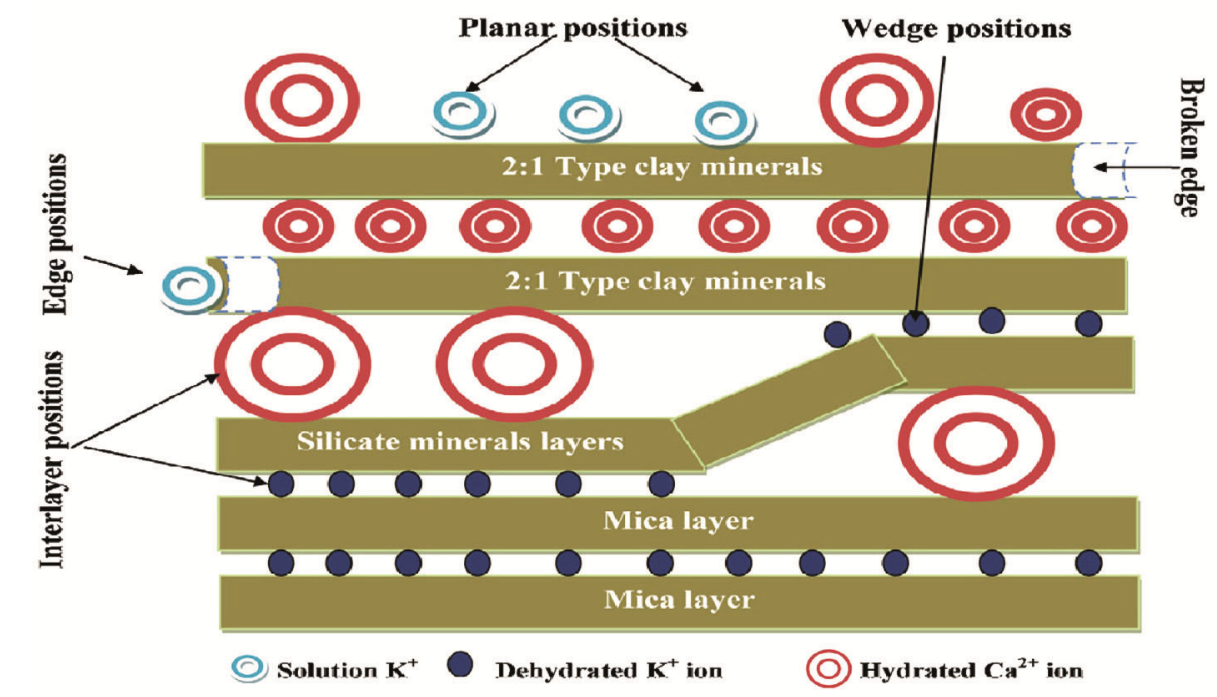

Figure 1. Potassium adsorption positions for $\mathrm{K}^{+}$in a mica-silicate mineral in the soil system (source: Meena et al. $^{86}$ ).

forms of potassium. The lower concentration of $\mathrm{K}$ in the soil solution induces the release of $\mathrm{K}^{+}$from nonexchangeable $\mathrm{K}$ (ref. 12). The $\mathrm{K}$ content in the soil solution ranges from 2 to $5 \mathrm{mg} \mathrm{K} \mathrm{l}^{-1}$ for normal agricultural soils of humid regions ${ }^{13}$. The levels of solution $\mathrm{K}$ are affected by the kinetic and equilibrium reactions that occur between the $\mathrm{K}$ forms, the concentrations of bivalent cations on the exchanger and in solution phase and moisture content ${ }^{14,15}$.

Exchangeable $\mathrm{K}$ is the form of soil $\mathrm{K}$ which is electrostatically bound as an outer-sphere complex to the surface of clay minerals and humic substances ${ }^{16}$. The amount of $\mathrm{K}^{+}$held by clay minerals at exchange sites depends on thermodynamic as well as kinetic factors ${ }^{17}$, and the affinity of the exchange sites for $\mathrm{K}^{+}$is related to the concentration and nature of the soil surface of $\mathrm{K}^{+}$in relation to the other exchangeable and mostly divalent cations present in the soils ${ }^{18}$. It is exchanged with other cations and is also readily available to plants ${ }^{19}$.

Non-exchangeable/fixed $\mathrm{K}$ is held between the layers of clay minerals and is not easily available for exchange with other cations. It is held between adjacent tetrahedral layers of dioctahedral and trioctahedral micas, vermiculites and intergrade clay minerals such as chloritized vermiculite $^{11,14,20}$. The binding forces between $\mathrm{K}$ and the clay surfaces are greater than the hydration forces between individual $\mathrm{K}^{+}$ions, resulting in potassium fixation. This results in a partial collapse of the crystal structures and the $\mathrm{K}^{+}$ions are physically trapped to varying degrees, making $\mathrm{K}$ release a slow, diffusion-controlled process ${ }^{11}$. Several types of adsorption sites for $\mathrm{K}^{+}$on clay minerals have been postulated (Figure 1$)^{21}$. Those on planar surfaces (p-position) have low $\mathrm{K}^{+}$selectivity; however, the edge (e-position) and wedge (w-position) have medium $\mathrm{K}^{+}$selectivity. The $\mathrm{K}^{+}$present in interlayer edge and wedge positions (Figure 1) is known as fixed K. The factors responsible for $\mathrm{K}$ fixation are the particle size distribution, types and quantities of clay minerals, and the addition or removal of $\mathrm{K}$ from minerals ${ }^{22}$.

Structural $\mathrm{K}$ is also known as mineral $\mathrm{K}$. It is bonded covalently within the crystal structure of K-bearing minerals like micas and feldspars ${ }^{23}$. Structural $\mathrm{K}$ is generally assumed to be only slowly available to plants; however, the availability is dependent on the level of $\mathrm{K}$ in the other forms, and the degree of weathering of the micas and feldspars constituting the mineral $\mathrm{K}$ fraction ${ }^{11,14}$. The $\mathrm{K}$ forms of the soil in the order of their availability to plants are: solution $>$ exchangeable $>$ non-exchangeable (fixed) $>$ structural $^{11,14,15}$.

\section{Status of potassium in Indian soil}

Potassium is one of the three main nutrients of balanced fertilizer use, coupled with nitrogen and phosphorus. India is the third largest user of $\mathrm{N}, \mathrm{P}$ and $\mathrm{K}$ fertilizers in the world, with an annual consumption at about 18 million tonnes $(\mathrm{mt})$ of $\mathrm{N}+\mathrm{P}_{2} \mathrm{O}_{5}+\mathrm{K}_{2} \mathrm{O}$, of which $\mathrm{K}$ comprises only one-seventh of the total ${ }^{3,24}$. The net negative balance for $\mathrm{N}, \mathrm{P}$ and $\mathrm{K}$ in the current agricultural scenario is $19 \% \mathrm{~N}, 12 \% \mathrm{P}$ and $69 \% \mathrm{~K}$. This huge negative difference of potassium is partly because crops remove an average of 1.5 times more potassium than nitrogen, and the application of potassium through fertilizers is considerably lower than that of $\mathrm{N}$ or $\mathrm{P}$ (refs 3, 7). The assessment of potassium status of Indian soils in 1929 suggested that soil $\mathrm{K}$ status was sufficient. Stewart ${ }^{25}$ partially modified this and reported that most of the soils have adequate potassium, except the lateritic soils. Tamhane and Subbiah $^{26}$ reported that, out of 35,000 soil 
Table 1. Status of potassium (K) in shrink-swell soils (Vertisols and Vertic intergrades) of India

\begin{tabular}{|c|c|c|c|c|c|c|}
\hline \multirow[b]{2}{*}{ Sampling location ${ }^{\mathrm{a}}$} & \multirow[b]{2}{*}{ Soil type } & \multicolumn{2}{|c|}{$\begin{array}{l}\text { Range and mean (mean within brackets) } \\
\qquad\left(\mathrm{mg} \mathrm{kg}^{-1}\right)\end{array}$} & \multirow[b]{2}{*}{$\mathrm{HNO}_{3} \mathrm{~K}$} & \multirow[b]{2}{*}{ Non-exchangeable $\mathrm{K}^{\mathrm{d}}$} & \multirow[b]{2}{*}{ Source (ref.) } \\
\hline & & Water-soluble $\mathrm{K}^{\mathrm{b}}$ & Exchangeable $\mathrm{K}^{\mathrm{c}}$ & & & \\
\hline Nabibagh, Bhopal & Typic Haplustert & $5-13$ & $171-252 \mathrm{H}$ & - & $\mathrm{H}$ & 87 \\
\hline Raipur, Chhattisgarh & Vertisols & 16.3 & $102 \mathrm{M}$ & - & $788 \mathrm{H}$ & 88 \\
\hline Jhalawar, Rajasthan & Vertisols & 98 & $121 \mathrm{H}$ & 743 & $637 \mathrm{H}$ & 89 \\
\hline Indore, Madhya Pradesh & Vertisols & $4-16(10)$ & $101-147(132) \mathrm{M}-\mathrm{H}$ & - & - & 36 \\
\hline Rewa, Madhya Pradesh & Vertisols & $6-14(9)$ & 141-208(171) H & - & - & 90 \\
\hline Vidharbha, Maharashtra & Vertisols & 8 & $135 \mathrm{H}$ & - & $>600 \mathrm{H}$ & 91 \\
\hline Akola, Maharashtra & Vertisols & $1-2(1)$ & 13-69 (32) L-M & - & $\mathrm{M}$ & 36 \\
\hline Solapur, Maharashtra & Vertisols & $2-5$ & $198-256(217) \mathrm{H}$ & 520 & $640-720(661)$ & 36 \\
\hline Andhra Pradesh & Vertisols & $2-4$ & $\mathrm{H}$ & $\mathrm{H}$ & $>600 \mathrm{H}$ & 92 \\
\hline $\begin{array}{l}\text { Telangana and Rayalseema } \\
\text { districts }\end{array}$ & Vertisols & 15 & $\mathrm{H}$ & - & $\mathrm{H}$ & 93 \\
\hline Karnataka (north) & Vertisols & 20 & $212(\mathrm{H})$ & - & $625(\mathrm{H})$ & 95 \\
\hline Sadhugarh, Punjab & Vertic Ustochrepts & - & $221.2(\mathrm{H})$ & - & $\mathrm{H}$ & 96 \\
\hline Sehore, Madhya Pradesh & Vertisols & 7.7 & $\mathrm{H}$ & 821 & $\mathrm{H}$ & 88 \\
\hline Nimone, Maharashtra & Udic Chromusterts & - & $310(\mathrm{H})$ & - & $540(\mathrm{M})$ & 97 \\
\hline Dhule, Maharashtra & Typic Chromusterts & 12.4 & $455(\mathrm{H})$ & 1072 & $617(\mathrm{H})$ & 98 \\
\hline Western Gujarat & Black soil & 5.98 & $148(\mathrm{H})$ & 499 & $383(\mathrm{M})$ & 99 \\
\hline Saurastra, Gujarat & Black soils & 11 & $171(\mathrm{H})$ & 610 & $438(\mathrm{M})$ & 100 \\
\hline Gujarat (Pithvajal, Amreli) & Vertic Ustochrept & 13 & $\mathrm{H}$ & 580 & $600-800$ & 42 \\
\hline $\begin{array}{l}\text { Kamliakheri, Indore, } \\
\text { Madhya Pradesh }\end{array}$ & Vertic Ustochrept & 9 & $265(\mathrm{H})$ & 800 & $>1000(\mathrm{H})$ & 65 \\
\hline
\end{tabular}

${ }^{\mathrm{a}}$ Number of states or agro-ecological regions/locations sampled. ${ }^{\mathrm{b}}$ Mean of water-soluble K. ${ }^{\mathrm{c}}$ Values within brackets represent mean of exchangeable $\mathrm{K}$ (available $\mathrm{K}$ water - soluble $\mathrm{K}$ ). ${ }^{\mathrm{d}}$ Non-exchangeable $\mathrm{K}$ is $\mathrm{HNO}_{3} \mathrm{~K}$ minus exchangeable $\mathrm{K}$. ${ }^{\mathrm{e}} \mathrm{In}$ some cases, range is given with or without mean. Values within brackets represent the mean. Exchangeable $\mathrm{K}: 0-50 \mathrm{mg} \mathrm{kg}^{-1}$ low (L), 50-110 mg kg ${ }^{-1} \mathrm{medium}(\mathrm{M})$ and above $110 \mathrm{mg} \mathrm{kg}{ }^{-1}$ high (H).

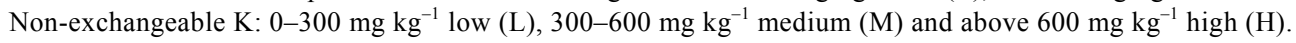

samples analysed from different states in India, 64\% were low to medium in potassium. Thereafter Ramamoorthy and Bajaj $^{27}$ reported that out of 1.3 million soil samples analysed, $20 \%$ were low, $53 \%$ medium and $27 \%$ were high in $\mathrm{K}$ status. The available potassium status generated in 1976 provided the benchmark information ${ }^{28}$. Most of the Indian soils are categorized as medium to high in available potassium status. Motsara and $\mathrm{Singh}^{29}$, and Motsara $^{30}$ have also assessed the $\mathrm{K}$ fertility status of Indian soils. The nutrient index values based on more than 11 million soil test data from 371 districts, showed that $76(21 \%)$ were low in K, 190 (51\%) were medium and $105(28 \%)$ were high in $\mathrm{K}$ (ref. 31). Muralidharudu et $a .^{32}$ studied $\mathrm{K}$ fertility status of 500 districts and reported that $9 \%$ districts were low in $\mathrm{K}, 42 \%$ were medium and $49 \%$ were high in $\mathrm{K}$. These data are based on $1 \mathrm{~N} \mathrm{NH}_{4} \mathrm{OAc}$ method; the soils containing $130 \mathrm{~kg}$ $\mathrm{K}_{2} \mathrm{O} /$ ha were categorized as low, $130-335 \mathrm{~kg} \mathrm{~K}_{2} \mathrm{O} / \mathrm{ha}$ as medium and above $335 \mathrm{~kg} \mathrm{~K}_{2} \mathrm{O} / \mathrm{ha}$ were categorized as high $^{33}$. Shrink-swell soils comprising Chromusterts, Pellusterts and Vertic Ustochrepts are found in the central highlands (Malwa, Budelkhand and East Satpura), Gujarat plains, Kathiawar peninsula, Deccan and the Eastern Ghats. They are high in exchangeable and medium to high in non-exchangeable $\mathrm{K}$ (ref. 34). To categorize the shrink-swell soils in different regions on the basis of available $\mathrm{K}\left(1 \mathrm{~N} \mathrm{NH} \mathrm{NH}_{4} \mathrm{OAc}\right.$ extractable as described by Jackson $\left.{ }^{10}\right)$, non-exchangeable $\mathrm{K}$ (1N boiling $\mathrm{HNO}_{3}$ extractable minus $1 \mathrm{~N} \mathrm{NH} \mathrm{NH}_{4} \mathrm{OAc}$ extractable as described by Jackson) ${ }^{10}$, water-soluble $\mathrm{K}$ (determined after extracting $\mathrm{K}$ from soil in water and using a flame photometer) and exchangeable $\mathrm{K}$ (derived by subtracting watersoluble $\mathrm{K}$ from available $\mathrm{K}$; Table 1), the following norms were employed:

- Exchangeable $\mathrm{K}\left(\mathrm{mg} \mathrm{kg}^{-1}\right)$ : low (0-50), medium (50110) and high $(>110)^{33}$.

- Non-exchangeable $\mathrm{K}\left(\mathrm{mg} \mathrm{kg}^{-1}\right)$ : low (0-300), medium $(300-600)$ and high $(>600)^{35-37}$.

\section{Pattern of potassium consumption and nutrient mining in India}

The annual consumption of $\mathrm{K}$ was insufficient around $3000-6000$ tonnes in the early 1950 s and it reached up to $0.3 \mathrm{mt}$ after 20 years. The potassium consumption increased from 0.3 to $1.36 \mathrm{mt}$ between $1971-72$ and 199192 (ref. 38). Temporal data for more than 50 years in India showed that potassium contributes to less than $10 \%$ of the total fertilizer nutrient consumption ${ }^{39}$. The consumption of $\mathrm{K}$ is only $22 \%$ when compared to nitrogen consumption. 


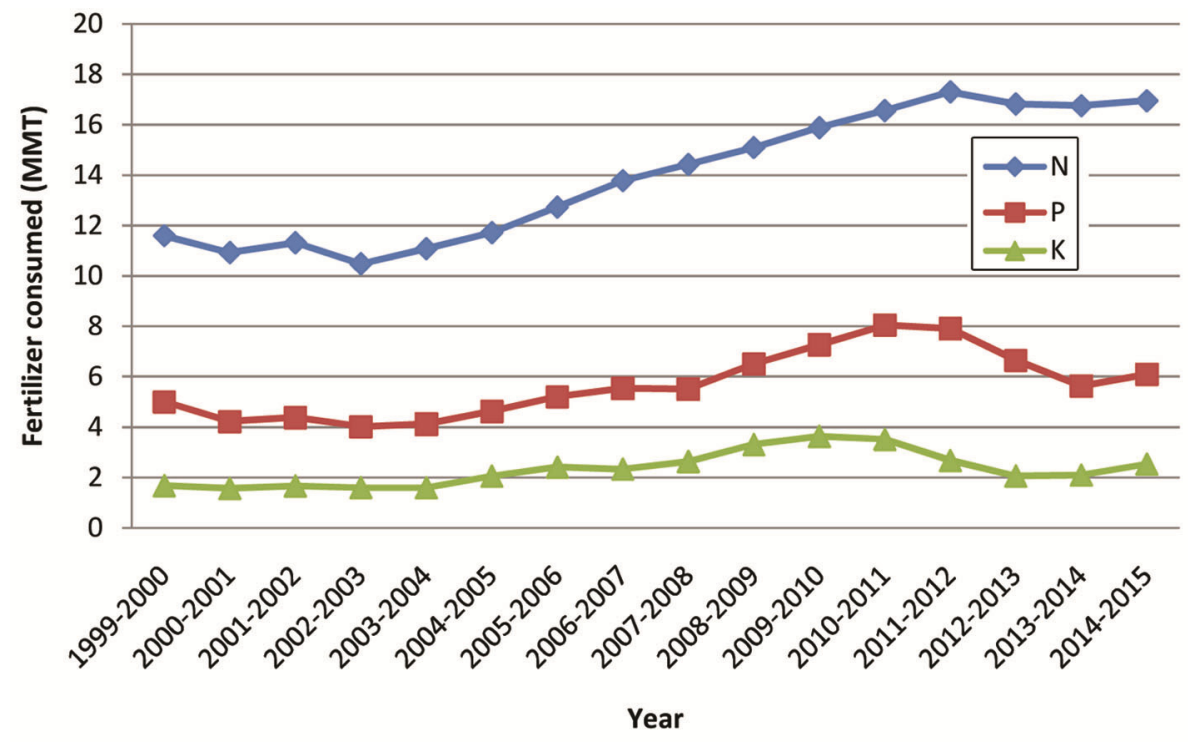

Figure 2. Trend of fertilizer consumption (N, P and $\mathrm{K})$ in India.

The potassium consumption dropped from $1.36 \mathrm{mt}$ in 1991-92 to $0.88 \mathrm{mt}$ in 1992-93 due to decontrol, which increased the price of potassium fertilizers. After realizing the problem, the Government of India (GoI) had introduced a concession scheme to increase potash consumption by lowering maximum retail prices. Thereafter, potassium consumption increased and touched a record high of $3.63 \mathrm{mt}$ in 2009-10 (Figure 2), and by $2025 \mathrm{~K}_{2} \mathrm{O}$ consumption may be doubled to meet the foodgrain needs of the country. India has no deposits of $\mathrm{K}$ fertilizers, and all of them have to be imported. However, the major concern is the rapidly increasing price of muriate of potassium (MOP). It was Rs 5055/mt in 201011 and rose to Rs $17,892 / \mathrm{mt}$ in $2014-15$ and continues to

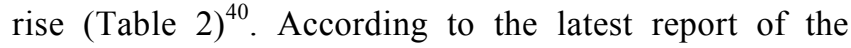
Cabinet Committee on Economic Affairs, with the recent revision in nutrient-based subsidy (NBS) rates, the MRP for MOP could increase by about Rs $800-1000 / \mathrm{mt}$.

Currently, GoI is spending about Rs. 9280/tonnes on K fertilizers to supply the farmers (Table 3$)^{41}$. The consumption of $\mathrm{N}$ and $\mathrm{P}$ registered a decline of $3.7 \%$ and $3.9 \%$ respectively, during 2016-17 over the previous year. However, potassium consumption increased by $4.4 \%$ during 2016-17 (ref. 41). This scenario underlies the need for using the costly $\mathrm{K}$ fertilizer judiciously and most economically, considering the crop $\mathrm{K}$ needs and soil $\mathrm{K}$ reserves $^{42}$. In case of nutrient mining, the balance sheets of nutrients in most of the Indian soils have been negative, and continue to be so. Based on nutrient balance sheets data published in Fertilizer News, Tandon ${ }^{7}$ has condensed the state-level nutrient balance sheets (Table 4) and soil nutrient balance sheets of India (Table 5). The balance is positive for nitrogen and phosphorus, whereas it is negative for potassium on a gross basis. The net figures arrived after adjusting fertilizer input use efficien- cies was $50 \%$ for $\mathrm{N}, 35 \%$ for $\mathrm{P}_{2} \mathrm{O}_{5}$ and $70 \%$ for $\mathrm{K}_{2} \mathrm{O}$ (Table 5). In case of removal, $60 \%$ crop uptake was for $\mathrm{K}$ only, whereas for both $\mathrm{N}$ and $\mathrm{P}$ it was $80 \%$ (Table 5). As evident from Table 5, potassium has maximum negative balance followed by nitrogen, whereas it is lowest for phosphorus.

\section{Clay mineralogy vis-á-vis forms of potassium}

The potassium release from clay minerals is influenced by chemical composition and particle size of these minerals ${ }^{43}$. It is a well-accepted fact that trioctahedral micas, such as phlogopite and biotite, release potassium more easily than dioctahedral micas, such as muscovite ${ }^{44}$. Several studies have demonstrated the relationship between clay mineralogy composition and forms of potassium $^{45-50}$. The knowledge of clay mineralogy is essential for understanding the elemental composition and nutrient supplying power of the soils. $\mathrm{K}$ dynamics is principally influenced by the mineralogical composition of soils ${ }^{48}$. The relationship between clay mineralogy and potassium forms can be used in evaluating potential soil $\mathrm{K}$ fertility, prediction of clay cycling and plant uptake ${ }^{45}$. Information on exchangeable $\mathrm{K}\left(1 \mathrm{~N} \mathrm{NH}_{4} \mathrm{OAc}\right)$ combined with knowledge of clay mineralogical composition can provide an understanding about the equilibrium and release of non-exchangeable $\mathrm{K}$ to plants and the need for potassic fertilizers ${ }^{46}$.

Soils abundant in $2: 1$ clay minerals such as highcharge smectites, vermiculite and micas contain a huge amount of $\mathrm{HNO}_{3}$-extractable potassium than kaolinite and other siliceous minerals ${ }^{45,47,48}$. Bhonsle et al. ${ }^{46}$ reported that kaolinitic soils had low levels of exchangeable K ( $1 \mathrm{~N}$ $\mathrm{NH}_{4} \mathrm{OAc}$ ), illitic and mixed soils had medium level, and 
Table 2. Retail price (MRP) in Rs/MT of Muriate of potassium (MOP) under the NBS regime

\begin{tabular}{lrrrr}
\hline & \multicolumn{4}{c}{ Price (quarter-wise, Rs/million tonnes (MT) } \\
\cline { 2 - 5 } Year & I & II & III & IV \\
\hline $2010-11$ & 5055 & 5055 & 5055 & 5055 \\
$2011-12$ & 6064 & 11,300 & 12,040 & 12,040 \\
$2012-13$ & 16,695 & 23,100 & 24,000 & 18,750 \\
$2013-14$ & 18,638 & 17,750 & 17,750 & 17,750 \\
$2014-15$ & 17,892 & 17,892 & 17,892 & 16,980 \\
\hline
\end{tabular}

Source: Ref. 40 .

Table 3. Subsidy on MOP fertilizer during $2011-12$ to $2015-16$

\begin{tabular}{lc}
\hline Year & Subsidy (Rs/tonne) \\
\hline $2011-12$ & 16,054 \\
$2012-13$ & 14,400 \\
$2013-14$ & 11,300 \\
$2014-15$ & 9,300 \\
$2015-16$ & 9,300 \\
$2016-17$ & 9,280 \\
\hline
\end{tabular}

Source: Ref. 41.

smectitic soils had high levels of exchangeable K. Sharp$1 y^{45}$ reported that determination of both non-exchangeable and exchangeable $\mathrm{K}$ could give better indication of potential potassium supplying power of the soil.

\section{Role of minerals in potassium availability}

The primary K-bearing minerals in soils are micas and K-feldspars. Micas are more important than potassium feldspars in supplying potassium to plant ${ }^{20,51}$. Plantavailable potassium, however, is related to the weathering of micas and feldspars in soil environment ${ }^{51}$. The contribution of potassium to the soil pool from feldspars is meagre because the process of $\mathrm{K}$ release is a very slow reaction in natural soil environment ${ }^{52,53}$. In micas, a large unhydrated $\mathrm{K}$-ion is held in ditrigonal cavities of the basal plane of oxygen of the tetrahedral sheets by electrostatic bonds. This keeps the layer collapsed ${ }^{51}$. Trioctahedral micas release their $\mathrm{K}$ by weathering more easily than dioctahedral micas ${ }^{54}$. Serratosa and Bradly ${ }^{55}$ observed that the proton of $\mathrm{OH}$ in trioctahedral micas is repelled equally by all the three octahedral cations, and lies on the normal to the basal plane, directed towards the interlayer space. In dioctahedral micas the proton is attracted to the vacant octahedral site and is displaced to one side of the normal. $\mathrm{K}$ in trioctahedral micas is repelled to a certain extent by the proton, and is therefore in a less electronegative environment than $\mathrm{K}$ in dioctahedral micas ${ }^{56}$. This implies that $\mathrm{K}$ is held more strongly in dioctahedral mica as compared to trioctahedral micas.

The concentration of potassium in soil solution is the most important factor that controls the rate of release of
$\mathrm{K}$ from micas ${ }^{51}$. Pal et $a l .{ }^{57}$ reported that performing experiments to relate $\mathrm{K}$ release reaction of Indian soils without ascertaining the nature and composition of soil micas may not be adequate to establish a relationship between crop response to potassium fertilizers and nature of soil micas. Mica, hydrous mica and vermiculite have high adsorption/fixation properties ${ }^{16,58-60}$, whereas smectites do not fix or adsorb $\mathrm{K}$ due to their low charge ${ }^{59,61-63}$. Research on the fundamental aspects of potassium release and adsorption/fixation in relation to the mineralogy of soils gained momentum during 1985 to 2001 in $\operatorname{India}^{64,65}$. The role of potassium-bearing minerals in releasing $\mathrm{K}$ from their non-exchangeable fraction of Indian soils is well established ${ }^{42,66-69}$. Micas are prime K-bearing minerals of major Indian soils that are mainly concentrated in their clay and silt fractions ${ }^{59,70-74}$. Despite this favourable $\mathrm{K}$-mineral inheritance, crop response to potassium fertilizers in many of these soils has been anomalous ${ }^{59,73-75}$. Both trioctahedral and dioctahedral micas are common in these soils ${ }^{59,73-75}$. Therefore, release of $\mathrm{K}$ from finegrained micas is not similar because they are far from ideal in composition and structure ${ }^{51}$. The proposed relationships between potassium release and micas are based on results obtained from specimen micas and not from soil micas, and thus they are speculative ${ }^{20,60,76,77}$. The mica present in black soils contains both biotite and muscovite minerals ${ }^{74}$, which is confirmed from the ratio of peak heights of 001 and 002 mica basal reflections. A ratio greater than one suggests the muscovitic characteristic of mica, but in reality, it indicates the presence of both biotite and muscovite minerals ${ }^{74}$. The ratio would have been very close to unity if muscovite minerals alone are present $^{78}$. Pal et al. ${ }^{60}$ observed a significant positive correlation between cumulative $\mathrm{K}$ release from sand, silt and clay, and their total $\mathrm{K}$ content, indicating that potassium release is a function of total $\mathrm{K}$ content in feldspars and micas. He further observed a positive correlation between total potassium content in soil, sand, silt and clay, and also highlighted the influence of mica to supply potassium to the plants grown in black soils. However, better correlation between potassium release in soil, sand, silt and clay and their biotite content provided undeniable evidence that the $\mathrm{K}$ release in soils is primarily controlled by biotite ${ }^{60}$. 
Table 4. Nitrogen $(\mathrm{N})$ and potassium oxide $\left(\mathrm{K}_{2} \mathrm{O}\right)$ addition, removal and balance in major states ('000 t)

\begin{tabular}{|c|c|c|c|c|c|c|}
\hline \multirow[b]{2}{*}{ State } & \multicolumn{3}{|c|}{$\mathrm{N}$} & \multicolumn{3}{|c|}{$\mathrm{K}_{2} \mathrm{O}$} \\
\hline & Addition & Removal & Balance & Addition & Removal & Balance \\
\hline Maharashtra & 923 & 1559 & -636 & 197 & 2096 & -1899 \\
\hline Uttar Pradesh & 2387 & 1497 & 889 & 114 & 1777 & -1664 \\
\hline Rajasthan & 547 & 835 & -288 & 7 & 1068 & -1061 \\
\hline Madhya Pradesh & 519 & 696 & -177 & 24 & 849 & -825 \\
\hline Punjab & 1081 & 589 & 492 & 19 & 764 & -745 \\
\hline Andhra Pradesh & 1256 & 477 & 779 & 191 & 817 & -625 \\
\hline Haryana & 597 & 362 & 235 & 5 & 490 & -485 \\
\hline Karnataka & 681 & 473 & 209 & 216 & 604 & -388 \\
\hline Gujarat & 691 & 340 & 351 & 61 & 426 & -365 \\
\hline Odisha & 196 & 227 & -31 & 40 & 282 & -242 \\
\hline Tamil Nadu & 484 & 405 & 79 & 162 & 398 & -236 \\
\hline West Bengal & 562 & 764 & -202 & 226 & 801 & -575 \\
\hline All India & 10,923 & 9613 & 1310 & 1454 & 11,657 & $-10,203$ \\
\hline
\end{tabular}

Source: Tandon ${ }^{7}$.

Table 5. N, P and K balance sheets in India

\begin{tabular}{lrrrrrrr}
\hline & \multicolumn{2}{c}{ Gross balance sheet ('000 t) } & & \multicolumn{3}{c}{ Net balance sheet ('000 t) } \\
\cline { 2 - 3 } Nutrient & Addition & Removal & Balance & & Addition & Removal & Balance \\
\hline $\mathrm{N}$ & 10,923 & 9613 & 1310 & & 5461 & 7690 & -2229 \\
$\mathrm{P}_{2} \mathrm{O}_{5}$ & 4188 & 3702 & 486 & & 1466 & 2961 & -1496 \\
$\mathrm{~K}_{2} \mathrm{O}$ & 1454 & 11,657 & $-10,202$ & & 1018 & 6994 & -5976 \\
NPK total & 16,565 & 24,971 & -8406 & & 7945 & 17,645 & -9701 \\
\hline
\end{tabular}

Source: Tandon ${ }^{7}$.

\section{Status of potassic fertilizer consumption in India}

It is well known that $\mathrm{K}$ consumption in India mainly depends on availability of potassium, maximum retail prices and availability of potassium-carrying complexes in the region $^{38}$. During the last one and a half decades, urea availability has been satisfactory; but it was unsatisfactory in case of other fertilizer products. During 2016-17, import of urea and diammonium phosphate (DAP) reduced significantly from the level of the previous year. Import of MOP, however, showed an increase during the period. Import of urea was 5.48 million metric tonnes (MMT) in 2016-17 as against 8.47 MMT in the previous year. Import of DAP also declined to 4.39 MMT in 201617 from 6.01 MMT in the previous year. However, import of MOP increased to 3.74 MMT in 2016-17 from 3.24 MMT in the previous year ${ }^{40}$. As we know Indian companies import potassium from Jordan, Canada, Belarus, the UK, CIS, Germany and Israel. Total imports of MOP in 2007-08 were 44.21 lakh tonne, which increased to 56.7 lakh tonnes in 2008-09. Table 6 shows Indian import statistics of potassium fertilizers from various countries.

Table 7 shows the quantity of nitrogen, phosphorus and potassium fertilizers imported during the last 12 years (up to January 2015). Fertilizers like DAP, urea, SSP and various grades of complex fertilizers are being produced in the country. However, the gap between estimated requirement and indigenous production is being met through imports. MOP is the only fertilizer whose requirement is fully met through imports, as there are no feasible existing sources of MOP in the country ${ }^{40}$. Scarcity in the availability of $\mathrm{K}$ and $\mathrm{K}$-carrying complexes is the major reason for import and skewed NPK ratio in India. In fact, historically, nutrient management in India has been $\mathrm{N}$-driven, followed by $\mathrm{P}$ and very less of $\mathrm{K}$, which is the key reason for diminishing low nutrient use efficiency $^{79}$. The low use of potassium in crops is due to the perception that the Indian soils are rich in $\mathrm{K}$, and reduction in potassium use will help the national exchequer as India imports its entire potassium fertilizer requirement ${ }^{80,81}$. This has resulted in neglected use of $\mathrm{K}$ fertilizers by farmers ${ }^{82}$.

It is worth noting that even the most productive and progressive states like Haryana and Punjab have skewed $\mathrm{N}: \mathrm{P}: \mathrm{K}$ ratios. Traditionally, the focus has been on nitrogen application followed by phosphorus with very less use of potassium, resulting in a huge imbalance. The deficiency of potassium in Indian agriculture in 2020 is predicted to be around $10 \mathrm{mt} / \mathrm{annum}$, whereas estimates of nitrogen and phosphorus balances are positive ${ }^{65,67}$. The general tendency of Indian farmers is to purchase whichever fertilizer is available in the market. The effect of $\mathrm{N}$ and $\mathrm{P}$ fertilizers is seen within a short time of 


\begin{tabular}{lccccccc}
\multicolumn{7}{c}{ Table 6. Import of K fertilizer in India } \\
\hline Country & $2003-04$ & $2004-05$ & $2005-06$ & $2006-07$ & $2007-08$ & $2008-09$ & Percentage imports \\
nyyyyynn $2008-09$ \\
\hline CIS* & 10.98 & 15.36 & 23.57 & 16.24 & 12.58 & 21.09 & 37 \\
Canada & 4.51 & 6.45 & 8.12 & 7.02 & 10.66 & 14.04 & 25 \\
Israel & 2.55 & 6.4 & 6.89 & 4.82 & 11.25 & 11.43 & 20 \\
Jordan & 6.58 & 4.79 & 5.5 & 4.17 & 7.66 & 7.45 & 13 \\
Germany & 1.18 & 0.91 & 1.43 & 1.26 & 1.65 & 1.53 & 3 \\
UK & - & - & - & - & 0.19 & 1.12 & 2 \\
Total & 25.8 & 34.09 & 45.78 & 34.48 & 44.21 & 56.72 & \\
\hline
\end{tabular}

*Commonwealth of independent states. Source: Anon. ${ }^{101}$.

Table 7. Import of $\mathrm{N}, \mathrm{P}$ and $\mathrm{K}$ fertilizers in India

\begin{tabular}{lccc}
\hline & \multicolumn{3}{c}{ Quantity (in lakh metric tonnes) } \\
\cline { 2 - 4 } Year & Nitrogenous fertilizer & Phosphatic fertilizer & Potassic fertilizer \\
\hline $2003-04$ & 132 & 338 & 1548 \\
$2004-05$ & 411 & 296 & 2045 \\
$2005-06$ & 1385 & 1122 & 2747 \\
$2006-07$ & 2689 & 1322 & 2069 \\
$2007-08$ & 3707 & 1391 & 2653 \\
$2008-09$ & 3751 & 3067 & 3403 \\
$2009-10$ & 3447 & 2756 & 2945 \\
$2010-11$ & 4493 & 3802 & 4069 \\
$2011-12$ & 5240 & 4427 & 3335 \\
$2012-13$ & 3505 & 2625 & 1178 \\
$2013-14$ & 3920 & 1588 & 2537 \\
$2014-15$ & 4766 & 1832 & \\
\hline
\end{tabular}

Source: Department of Fertilizers, Government of India ${ }^{40}$.

application, whereas the effect of $\mathrm{K}$ application is seen only at maturity stage in the form of improvement in quality, shape, size and colour. Therefore, Indian farmers neglect potassium application in their fields. Hence, there is an urgent need to assess the expected responses to applied potassium so that potassium fertilizer management can be taken up for the efficient use of $\mathrm{K}$ and the resulting economy in potassium use ${ }^{65}$.

\section{Need for demand-driven research on potassium in shrink-swell soils}

Anamolies exist in shrink-swell soils as observed from the inconsistent crop response to applied $\mathrm{K}$ fertilizers. Generally the soils which contain less than $120 \mathrm{~kg} \mathrm{ha}^{-1} \mathrm{~K}$ are categorized as low in available potassium, between 120 and $280 \mathrm{~kg} \mathrm{ha}^{-1}$ as medium and above $280 \mathrm{~kg} \mathrm{ha}^{-1}$ as high in available $\mathrm{K}$ (refs 3,33 ). These rating limits are ambigious as they are classified irrespective of soils or crops. Solankey et al. ${ }^{83}$ studied the response of two wheat varieties to K on farmer's field in black soils and reported that though these soils were sufficient in $\mathrm{NH}_{4} \mathrm{OAc}-\mathrm{K}$, the crop responded to $30 \mathrm{~kg} \mathrm{ha}^{-1} \mathrm{~K}_{2} \mathrm{O}$. They have determined a critical limit for water-soluble $\mathrm{K}\left(14.4 \mathrm{~kg} \mathrm{ha}^{-1}\right)$, but failed to determine a critical limit based on $\mathrm{NH}_{4} \mathrm{OAc}-\mathrm{K}$. Raheb and Heidari ${ }^{84}$ observed that $\mathrm{NH}_{4} \mathrm{OAc}-\mathrm{K}$ extraction method does not give uniform trends in all mineralogical suits; a combination of both $\mathrm{NH}_{4} \mathrm{OAc}-\mathrm{K}$ and $\mathrm{HNO}_{3}-\mathrm{K}$ gives a more applicable index for illitic, vermiculitic and smectitic soils. This indicates that the $\mathrm{NH}_{4} \mathrm{OAc}$ method does not give proper indication of the viability of $\mathrm{K}$ in shrink-swell soils. Singh and Wanjari ${ }^{85}$ reported that soybean started showing a response to applied potassium fertilizer when available potassium status reached $316 \mathrm{~kg} \mathrm{ha}^{-1}$. However, wheat showed a response to potassium even earlier. Likewise, sorghum started showing response to applied potassium at $324.4 \mathrm{~kg} \mathrm{ha}^{-1}$, while a huge response in both the crops was noted at available potassium status of $307.6 \mathrm{~kg} \mathrm{ha}^{-1}$ in Akola, Maharashtra. Considering this crop response variation, we could take critical value for potassium as $312 \mathrm{~kg} \mathrm{ha}^{-1}$ (average of 307.6 and $316 \mathrm{~kg} \mathrm{ha}^{-1}$ ), but this value is greater than the threshold value $280 \mathrm{~kg} \mathrm{ha}^{-1}$ which is used to categorize the soil as high in available potassium. These results showed that in some situations, crop response to applied $\mathrm{K}$ may be poor in low K-containing soils, whereas significant responses to applied $\mathrm{K}$ are recorded in high $\mathrm{K}$ content soils. These anomalies need to be addressed for judicious K-fertilizer management. 


\section{REVIEW ARTICLES}

The critical levels to categorize soils into low, medium and high levels were set 50 years ago based on soil tests in the Indo-Gangetic plains. For example, Vertisols of central and southern India are categorized under high potassium level which leads to low potassium recommendation in this region. However, Vertisols with high clay content require more $\mathrm{K}$ compared to light textured soils of North India. Therefore, the yields are affected due to inaccurate recommendation for potassium application in Vertisols. Considering these prevailing anomalies, it has become need of the hour to revise the methodology for available potassium $\left(1 \mathrm{~N} \mathrm{NH}_{4} \mathrm{OAc}\right)$ in the soil, which is routinely followed throughout the country. Besides, the non-exchangeable $\mathrm{K}$, mineralogical composition, $\mathrm{K}$ fixing capacity as influenced by quality and quantity of clay under different soil, crop, and climatic conditions should also be taken into consideration for potassium recommendation. Therefore, the novel, holistic approach should envisage soil test crop response studies along with revision of existing K-testing methods, particularly for shrink-swell soils.

\section{Conclusion}

The available potassium status showed a gradual decline from medium to low in Indian shrink-swell soils. The routinely followed ammonium acetate method for potassium availability causes misinterpretation in shrink-swell soils of India. The fallacy that black soils (Vertisols) are rich in potassium has led to imbalanced potassium fertilizer recommendation causing deficiency in plants and soils. This paradoxical situation necessitates revision and revalidation of the existing potassium fertilizer recommendations, which are being adopted since four decades. India imports the entire quantity of potassic fertilizers, which gives an alarming call for judicious fertilizer management. A demand driven holistic research envisaging soil test crop response and mineralogical studies is the need of the hour for revising potassium evaluation methods in India. This research approach will optimize the input cost of $\mathrm{K}$ fertilizers and maintain soil health through judicious fertilizer management which will benefit the farmers in the long run.

1. Murthy, R. S., Bhattacharjee, J. C., Landey, R. J. and Pofali, R. M., Distribution, characteristics, and classification of Vertisols. In Vertisols and rice soils of the tropics, Symposia Paper II, 12th International Congress of Soil Science, Indian Society of Soil Science, New Delhi, 1982, pp. 3-22.

2. Bhattacharyya, T., Sarkar, D., Pal, D. K., Chandran, P., Ray, S. K. and Mandal, C., Potassium Status of Shrink-Swell Soils of India, vis-à-vis their Mineralogical Composition (eds Bhattachayya, T. et al.), International Symposium on Review and Refinement of Fertilizer $\mathrm{K}$ Recommendations in Vertisols, NBSS\&LUP, Nagpur, Maharashtra, 2010, pp. 1-4

3. Gurav, P. P., Ray, S. K., Choudhari, P. L., Biswas, A. K. and Shirale, A. O., A review on soil potassium scenario in Vertisols of
India. Open Access J. Sci., 2018(1); doi:10.15406/oajs.2018. 02.00051 .

4. Usherwood, N. R., The role of potassium in crop quality. Potassium in Agriculture (ed. Munson, R. D.), ASA/CSSA/SSSA, Madison, WI, USA, 1985, pp. 489-514.

5. Mengel, K. and Kirkby, E. A., Principles of Plant Nutrition, International Potash Institute, Worblaufen-Bern, Switzerland, 1987, p. 685.

6. Mengel, K. and Forster, H., The effect of the potassium concentration in the soil solution on the yield and the water consumption of sugar beets. Pflanzanerhr Bodenkunde, 1973, 134, 148-156.

7. Tandon, H. L. S., Soil nutrient balance sheets in India: importance, status, issues and concerns. In Better Crops India, International Plant Nutrition Institute (IPNI), 2007, pp. 15-17.

8. Swarup, A., Emerging soil fertility management issues for sustainable crop production in irrigated systems. In Long-Term Soil Fertility Management through Integrated Plant Nutrient Supply (eds Swarup, A., Damodar Reddy, D. and Prasad, R. N.), Indian Institute of Soil Science, Bhopal, 1998, pp. 54-68.

9. Swarup, A. and Ganeshmurthy, A. N., Emerging nutrient deficiencies under intensive cropping systems and remedial measures for sustainable high productivity. Fert. News, 1998, 43(7), 37-50.

10. Jackson, M. L., Soil Chemical Analysis, Prentice Hall of India Private Limited, New Delhi, 1968.

11. Sparks, D. L., Potassium dynamics in soils. Adv. Soil Sci., 1987, 6, 1-63.

12. Hay, M. J. M., Walker, T. W., Adams, A. F. R. and Campbell, A. S., The potassium status of six loessial soils of Canterbury, New Zealand, in relation to rainfall and rate of loess accumulation. J. Soil Sci., 1976, 27, 227-236.

13. Haby, V. A., Russelle, M. P. and Skogley, E. O., Testing soils for potassium, calcium, and magnesium. In Soil Testing and Plant Analysis (Third Edition) (ed. Westerman, R. L.), SSSA Book Series 3, Soil Science Society of America, Wisconsin, Madison, USA, 1990, pp. 181-227.

14. Sparks, D. L. and Huang, P. M., Physical chemistry of soil potassium. In Potassium in Agriculture (ed. Munson, R. D.), American Society of Agronomy, Crop Science Society of America, and Soil Science Society of America, Madison, WI, 1985, pp. 201-276.

15. Sparks, D. L., Bioavailability of soil potassium. In Handbook of Soil Science (ed. Sumner, M. E.), CRC Press, Boca Raton, FL, USA, 2000, pp. 38-52.

16. Malavolta, E., Potassium status of tropical and subtropical region soils. In Potassium in Agriculture (ed. Munson, R.), ASA, CSSA, and SSSA, Madison, Wisconsin, USA, 1985, pp. 163-200.

17. Parfitt, R. L., Potassium-calcium exchanges in some New Zealand soils. Aust. J. Soil Res., 1992, 30, 145-158.

18. Barber, S. A., Soil Nutrient Availability: A Mechanistic Approach, Wiley, New York, USA, 1984, p. 398.

19. Barré, P., Montagnier, C., Chenu, C., Abbadie, L. and Velde, B., Clay minerals as a soil potassium reservoir: observation and quantification through X-ray diffraction. Plant Soil, 2008, 302, 213-220.

20. Rich, C. I., Potassium in soil minerals. In Proceedings of 9th Colloquium of the International Potash Institute, Switzerland, 1972, pp. 15-31.

21. Goulding, K. W. T., Potassium fixation and release. In Proceedings of the Colloquium of the International Potash Institute, Switzerland, Berne, 1987, vol. 20, pp. 137-154.

22. Kirkman, J. H., Basker, A., Surapaneni, A. and MacGregor, A. N., Potassium in the soils of New Zealand-a review. N.Z. J. Agric. Res., 1994, 37, 207-227.

23. Metson, A. J., The long term potassium supplying power of New Zealand soils. In Transactions of the 9th International Congress of Soil Science, Adelaide, Australia, 1968, vol. 2, pp. 621-630. 
24. Hasan, R., Potassium status of soils of India. Better Crops Int., 2002, 16(2), 3-4

25. Stewart, A. B., Report on soil fertility investigation in India with special reference to manuring. Indian Council of Agricultural Research, New Delhi, 1947, p. 160.

26. Tamhane, R. V. and Subbiah, B. V., Correlation between soil analyses and response to fertilizers in special reference to rice crop in India. IRC Newsletter no. 9, 1960, pp. 1-10.

27. Ramamoorthy, B. and Bajaj, J. C., Available nitrogen, phosphorus and potassium status of Indian soils. Fert. News, 1969, 14(8), 25-36.

28. Ghosh, A. B. and Hasan, R., Available potassium status of Indian soils. J. Indian Soc. Soil Sci., 1976, 10, 1-5.

29. Motsara, M. R. and Singh, J., Soil testing for judicious use of fertilizers. Indian Farming, 1981, 56(9), 3-12.

30. Motsara, M. R., Available NPK status of Indian soils as depicted by soil fertility maps. Fert. News, 2002, 47(8), 15-21.

31. Hasan, R., Potassium status of soils of India. Bet Crops Int., 2002, 16(2), 3-4.

32. Muralidharudu, Y., Sammi Reddy, K., Mandal, B. N., Subba Rao, A., Singh, K. N. and Sonekar, S., GIS based soil fertility maps of different states of India. Indian Institute of Soil Science, Bhopal, 2011 .

33. Muhr, G. R., Datta, N. P., Shankara Subramoney, H., Leley, V. K. and Donahu, R. L., Soil testing in India. United States Agency for International Development, New Delhi, 1965, 120.

34. Subba Rao, A., Rupa, T. R. and Yadav, R. L., Assessing potassium needs of different crops and cropping systems in India. Indian Institute of Soil Science, Bhopal, 2010.

35. Subba Rao, A., Sesha Sai, M. V. R. and Pal, S. K., Nonexchangeable potassium reserves and their categorization in some soils of India. J. Indian Soc. Soil Sci., 1993, 41, 667-673.

36. Srinivasarao, Ch. et al., Potassium supplying characteristics of twenty-one soil profiles under diverse rainfed production systems. J. Indian Soc. Soil Sci., 2007, 55, 14-22.

37. Srinivasarao, Ch., Subba Rao, A., Rao, K. V., Venkateshwarlu, B. and Singh, A. K., Categorization of districts based on nonexchangeable potassium: implications in efficient $\mathrm{K}$ fertility management in Indian agriculture. Indian J. Fert., 2010, 6(7), 40-56.

38. Kinekar, B. K., Potassium fertilizer situation in India: current use and perspectives. Karnataka J. Agric. Sci., 2011, 24(1), 1-6.

39. Majumdar, K., Sanyal, S. K., Singh, V. K., Dutta, S. K., Satyanarayana, T. and Dwivedi, B. S., Potassium fertilizer management in Indian agriculture: current trends and future needs. Indian $J$. Fert., 2017, 13(5), 20-30.

40. Fertilizer Association of India (FAI), Indian Fertilizer Scenario, Department of Fertilizers, Ministry of Chemicals and Fertilizers, Government of India (GoI), 2015.

41. FAI, Indian Fertilizer Scenario, Department of Fertilizers, Ministry of Chemicals and Fertilizers, GoI, 2017.

42. Srinivasa Rao, Ch., Subba Rao, A. and Rupa, T., Plant mobilization of reserve potassium from fifteen smectitic soils in relation to mineralogy and soil test potassium. Soil Sci., 2000, 165, 578586.

43. Huang, P. M., Chemistry of potassium in soils. Soil Sci. Soc. Am. J., 2005, 227-292.

44. Fanning, D. S., Keramidas, V. Z. and El-Desoky, M. A., Micas. Soil Sci. Soc. Am. J., 1989, 551-634.

45. Sharpley, N., Relationship between soil potassium forms and mineralogy. Soil Sci. Soc. Am. J., 1989, 52, 1023-1028.

46. Bhonsle, N. S., Pal, S. K. and Sekhon, G. S., Relationship of K forms and release characteristics with clay mineralogy. Geoderma, 1992, 54, 285-293.

47. Liu, G., Nielsen, N. E., Hansen, H. C. B. and Borggaard, O. K., Mineral changes in a Danish Alfisol caused by 30 years of potassium depletion in the field. Soil Plant Sci., 1997, 47, 1-6.
48. Ghosh, B. N. and Singh, R. D., Potassium release characteristics of some soils of Uttar Pradesh hills varying in altitude and their relationship with forms of soil $\mathrm{K}$ and clay mineralogy. Geoderma, 2001, 104, 135-144.

49. Surapaneni, A., Palmer, A. S., Tillman, R. W., Kirkman, J. H. and Gregg, P. E. H., The mineralogy and potassium supplying power of some loessial and related soils of New Zealand. Geoderma, 2002, 110, 191-204.

50. Srinivasarao, Ch., Rupa, T. R., Subba Rao, A., Ramesha, G. and Bansal, S. K., Release kinetics of non-exchangeable potassium by different extractants from soils of varying mineralogy and depth. Soil Sci. Plant Anal., 2006, 37(3), 473-491.

51. Pal, D. K. and Srinivasa Rao, Ch., Role of minerals in potassium management of Indian soils. In International Seminar on Importance of Potassium in Nutrient Management for Sustainable Production in India, International Potash Institute, New Delhi, 3-5 December 2001, pp. 151-166.

52. Rasmussen, K., Potash in feldspars. In Proceedings of 9th Colloquium of the International Potash Institute, Switzerland, Basel, 1972, pp. 57-60.

53. Gurav, P. P., Datta, S. C., Ray, S. K., Choudhari, P. L. and Ahmed, N., Assessment of potassium release threshold levels of Vertisols (shrink-swell soils) in different agro-ecological regions of India. Appl. Clay Sci., 2018, 165, 155-163.

54. Mortland, M. M., Lowton, K. and Uehara, G., Fixation and release of potassium in some clay minerals. Proc. Soil Sci. Soc. Am., 1957, 21, 381-384.

55. Serratosa, J. M. and Bradley, W. F., The determination of $\mathrm{OH}$ bond axes inlayer silicates by infrared adsorption. J. Phys. Chem., 1958, 62, 1164-1167.

56. Bassett, W. A., Role of hydroxyl orientation in mica alteration. Bull. Geol. Soc. Am., 1960, 71, 449-456.

57. Pal, D. K., Srivastava, P., Durge, S. L. and Bhattacharyya, T., Role of weathering of fine-grained micas in potassium management of Indian soils. Appl. Clay Sci., 2001, 20(1), 39-52.

58. McLean, E. O. and Watson, M. E., Soil measurements of plantavailable potassium. In Potassium in Agriculture (ed. Munson, R.), ASA, CSSA, and SSSA, Madison, Wisconsin, USA, 1985, pp. 277-308.

59. Pal, D. K. and Durge, S. L., Potassium release and fixation reactions in some benchmark Vertisols of India in relation to their mineralogy. Pedologie, 1987, 37, 103-116.

60. Pal, D. K., Bhattacharyya, T., Chandran, P. and Ray, S. K., Linking minerals to selected soil bulk properties and climate change: a review. Clay Res., 2012, 31(1), 38-69.

61. Brindley, G. W., Ethylene glycol and glycerol complexes of smectite and vermiculite. Clay Miner., 1966, 6, 237-259.

62. Rich, I., Mineralogy of soil potassium. In The Role of Potassium in Agriculture (eds Kilmer, V. J., Younts, S. E. and Brady, N. C.), SSSA, Madison, Wisconsin, USA, 1968, pp. 79-96.

63. Ray, S. K., Chandran, P., Bhattacharyya, T., Durge, S. L. and Pal, D. K., Layer charge of two benchmark Vertisol clays by alkylammonium method. Clay Res., 2003, 22, 13-27.

64. Subba Rao, A. and Srinivasa Rao, Ch., Potassium status and crop response to $\mathrm{K}$ in different agro-ecological regions of India. IPI Research Topics No. 20, International Potash Institute, Basel, Switzerland, 1996, pp. 1-57.

65. Srinivasa Rao, Ch., Subba Rao, A. and Rupa, T., Need for inclusion of non-exchangeable potassium in soil test based potassium fertilizer recommendations. Fert. News, 2001, 46, 31-40.

66. Dhillon, S. K. and Dhillon, K. S., Kinetics of release of nonexchangeable potassium by cation saturated resins from red (Alfisols), black (Vertisols) and alluvial (Inceptisols) soils of India. Geoderma, 1990, 47, 283-300.

67. Srinivasa Rao, Ch. and Khera, M. S., Potassium replenishment capacity of some Ustochrepts at their minimal exchangeable $\mathrm{K}$ in relation to claymineralogy. J. Plant Nutr. Soil Sci., 1994, 157, 467-470. 


\section{REVIEW ARTICLES}

68. Srinivasa Rao, Ch., Khera, M. S. and Subba Rao, A., Soil potassium depletion and $\mathrm{K}$ replenishment capacity of soils under intensive cropping. J. Potassium. Res., 1994, 10, 229-235.

69. Srinivasa Rao, Ch., Pal, D. K. and Takkar, P. N., Mathematical models to study the kinetics of potassium desorption from swellshrink soils of central India in relation to mineralogy. J. Plant Nutr. Soil Sci., 1998, 16, 67-72.

70. Ghosh, S. K. and Bhattacharyya, T., Mineralogy of soils of Bihar, Uttar Pradesh, Gujarat and Rajasthan. In Mineralogy of Soil Potassium, PRII Research Review Series 1, Potash Research Institute of India, Gurgaon, 1984, pp. 15-29.

71. Pal, D. K. and Durge, S. L., Release and adsorption of potassium in some benchmark alluvial soils of India in relation to their mineralogy. Pedologie, 1989, 39, 235-248.

72. Pal, D. K. and Durge, S. L., Potassium release from clay micas. J. Indian Soc Soil Sci., 1993, 41, 67-69.

73. Pal, D. K., Deshpande, S. B. and Durge, S. L., Potassium release and adsorption reactions in two ferruginous (polygenetic) soils of southern India in relation to their mineralogy. Pedologie, 1993, 43, 403-415.

74. Pal, D. K., Bhattacharyya, T., Deshpande, S. B., Sharma, V. A. K. and Velayutham, M., Significance of Minerals in Soil Environment of India, NBSS Review Series 1, NBSS\&LUP, Nagpur, 2000 , p. 68.

75. Kapoor, B. S., Singh, H. B., Goswami, S. C., Abrol, I. P., Bhargava, G. P. and Pal, D. K., Weathering of micaceous minerals in some salt-affected soils. J. Indian Soc. Soil Sci., 1981, 29 486-492.

76. Sarma, V. A. K., Mechanisms and rate of release of potassium from potassium-bearing minerals in soils. In Mineralogy of Soil Potassium, PRII Review Series I, Potash Research Institute of India, Gurgaon, 1984, pp. 55-61.

77. Wilson, M. J., The origin and formation of clay minerals in soils: past, present and future perspective. Clay Miner., 1999, 34, 7-25.

78. Tan, K. H., Principles of Soil Chemistry, Marcel Dekker, New York, USA, 1982, p. 122.

79. Pathak, H., Trend of fertility status of Indian soils. Curr. Adv. Agric. Sci., 2010, 2(1), 10-12.

80. Sanyal, S. K., Majumdar, K. and Singh, V. K., Nutrient management in Indian agriculture with special reference to nutrient mining - a relook. J. Indian Soc. Soil Sci., 2014, 62, 307-325.

81. Majumdar, K., Sanyal, S. K., Dutta, S. K., Satyanarayana, T. and Singh, V. K., Nutrient mining: addressing the challenges to soil resources and food security. In Biofortification of Food Crops (eds Singh, U. et al.), Springer (India), New Delhi, 2016, pp. 177-198, ISBN 978-81-322-2714; doi:10.1007/978-81-322-27168-14.

82. Patra, A. K., Dutta, S. K., Dey, P., Majumdar, K. and Sanyal, S. K., Potassium fertility status of Indian soils: national Soil Health Card database highlights the increasing potassium deficit in soils. Indian J. Fert., 2017, 13(11), 28-33.

83. Solankey, B. S., Shinde, D. A., Yadav, K. S. and Singh, J., Response of wheat to $\mathrm{K}$ application in swell-shrink soils in relation to water-soluble K contents. J. Potassium Res., 1992, 7, 9-19.

84. Raheb, A. and Heidari, A., Clay mineralogy and its relationship with potassium forms in some paddy and non-paddy soils of northern Iran. Aust. J. Agric. Eng., 2011, 2(6), 169-175.

85. Singh, M. and Wanjari, R. H., Potassium Requirement of Crops Grown in Vertisols: Experiences from Long-term Fertilizer Expe- riment (eds Bhattachayya, T. et al.). In International Symposium on Review and Refinement of Fertilizer K Recommendations in Vertisols, 24-25 August 2010, NBSS\&LUP, Nagpur, 2010, pp. 11-13.

86. Meena, V. S., Maurya, B. R. and Verma, J. P., Does a rhizospheric microorganism enhance $\mathrm{K}^{+}$availability in agricultural soils? Microb. Res., 2014, 169, 337-347.

87. Srinivasarao, Ch. and Subbaiah, G. V., Association of some forms of potassium with soil acidity and mica content in six profiles of laterite soils. J. Potassium Res., 1997, 13, 12-20.

88. Srinivasarao, Ch., Ganeshamurthy, A. N., Masood, A., Singh, R. N. and Singh, K. K., Distribution of forms of potassium in different soil types of pulse growing regions of India. J. Potassium Res., 2002, 18, 23-30.

89. Das, K., Singh, S. K. and Shyampura, R. L., Forms of potassium in relation to landform and soil properties of basaltic terrain. J. Indian Soc. Soil Sci., 1993, 41, 557-559.

90. Srinivasarao, Ch., Vittal, K. P. R., Venkateswarlu, B., Tiwari, K. N., Chary, G. R. and Prasad, J. V. N. S., Emerging nutrient deficiencies in different soil types under rainfed production systems of India. In National Seminar on Integrated Nutrient Management in Rainfed Agro-ecosystems, CRIDA, Hyderabad, 3-4 March 2008 .

91. Gajbhiye, K. S., Gaikawad, S. T., Seghal, J. L., Bhaskar, K. S. and Gupta, R., Studies of available potassium and crop response in soils of Sawangi watershed in Vertisol region of Vidarbha. J. Potassium Res., 1993, 9, 233-240.

92. Surekha, K. and Subba Rao, A., Differential response of maize to potassium in Vertisols. J. Potash Res., 1997, 13, 261-265.

93. Surekha, K., Subba Rao, A., Prasad Rao, V. and Adinarayana, Long-term potassium releasing the power of Vertisols of Andhra Pradesh. J. Potash Res., 1996, 12, 345-350.

94. Krishnamurthy, V. and Ramakrishnayya, B. V., Potassium fertility of flue-cured tobacco growing soils of India. J. Potash Res., 1997, 13, 159-169.

95. Venkatesh, M. S. and Satyanarayana, T., Status and distribution of potassium in Vertisols of north Karnataka. J. Indian Soc. Soil Sci., 1994, 42, 239-233.

96. Pasricha, N. S., Sharma, B. D., Arora, C. L. and Singh, P. S., Potassium distribution in soils and ground waters of Punjab. J. Potassium Res., 2001, 17, 1-13.

97. Bele Nilima, R., Sonar, K. R. and Patil, Y. M., Quantity-intensity parameters of potassium in six dominant soil series of western Maharashtra. J. Potassium Res., 1997, 131, 31-36.

98. Sekhon, G. S., Brar, M. S. and Subba Rao, A., Potassium in some benchmark soils of India. Potash Research Institute of India, Gurgaon, 1992, pp. 1-82.

99. Patel, M. S., Hadvani, G. J. and Yadav, B. S., Fixation of potassium in important soil groups of Western Gujarat. J. Potassium Res., 1989, 5, 134-142.

100. Patel, M. S. and Golakia, B. A., Potassium in soils and crops of Gujarat. J. Potassium Res., 1996, 12, 48-58.

101. Anon., Fertilizer Statistics, FAI, New Delhi, 2008-09.

Received 13 December 2018; revised accepted 20 May 2019

doi: $10.18520 / \mathrm{cs} / \mathrm{v} 117 / \mathrm{i} 4 / 587-596$ 